\title{
Factors That Influence Nurse Turnover Intention In Sari Mulia Banjarmasin Hospital
}

\author{
$1^{\text {st }}$ St. Hateriah ${ }^{1}, 2^{\text {nd }}$ Esti Yuandari ${ }^{2}$ \\ \{siti.hateriah@yahoo.com ${ }^{1}$, yuandariesti@gmail.com ${ }^{2}$ \} \\ *Diploma Four in Health Promotion Universitas Sari Mulia
}

\begin{abstract}
Turnover is an important issue for hospitals and nurses, many nurses at Sari Mulia Hospital intend to turnover in the last 3 years. Nurse's turnover intention is influenced by many factors. Knowing and analyzing the factors that influence nurse turnover intention at Sari Mulia Hospital Banjarmasin. This study used an observational analytic method with a cross sectional approach. Sampling is done by probability sampling. The sample in this study was 60 people using a questionnaire. Data were analyzed using Pearson correlation test and logistic regression test. Based on the results of the analysis it was found that of the 60 most influential on intention turnover compensation was obtained $p$ value 0.005 with OR 0.217 . It is expected that the results of this study can be used as a reference for future researchers to examine other variables.
\end{abstract}

Keywords: factors, compensation, turnover intention, nurses

\section{INTRODUCTION}

According to WHO (World Health Organization), a hospital is an integral part of a social and health organization with the function of providing complete (comprehensive) services, healing diseases (curative) and prevention of diseases (preventive) to the community. The hospital is also a training center for health workers and medical research centers. In Indonesia the incidence of stopping or leaving the workplace for nurses often occurs in private hospitals. That is because private hospitals are a form of company that has rules and guidelines or commitments that are regulated internally that do not take into account the elements of benefit-cost and costeffectiveness for nurses (1).

According to Mobley (1986), the desire or intention to move to work (Turnover intention) is the tendency or intention of employees to stop working from their work. The problem of leaving or moving nurse's work is a classic problem that has occurred in organizations long ago as well as in hospitals (2). Sari Mulia Hospital is one of the private hospitals that has a high incidence of nurses who have changed jobs or been discharged from the hospital in the last 3 years. According to (3), the optimum standard of turnover or transfer of nurses in a hospital is 10\% every year.

Preliminary study conducted by researchers on June 8, 2016 at the Sari Mulia Hospital in Banjarmasin based on hospital staffing data. Sari Mulia the last 3 years the number of nurses who 
went out has increased, in 2014 the number of nurses 128 people, nurses who entered there were 17 people who came out 8 people (6.25\%), in 2015 the number of nurses 145 people, nurses who entered were 27 people and there were 23 people coming out (15.86\%), and the latest data in May 2016 were 147 nurses, 4 nurses entering and 12 nurses $(8.16 \%)$ were leaving. This is reinforced by research from Muthiah (4) proving that work stress, organizational climate, compensation, work environment, job characteristics, and job satisfaction simultaneously have a significant influence on the desire to leave.

Various ways will be taken by the organization in improving the performance of its employees in order to achieve the goals set, including the provision of fair compensation. According to (9) explains that the provision of compensation (rewards) should be associated with work performance (performance). Even though compensation has been based on performance criteria, if the workforce perceives as low, the result will be low work performance. Compensation should be regulated at a minimum using certain standards so as not to create the impression of injustice because it can trigger things that can affect employee performance and performance. . This study aims to determine and explain the factors that influence nurse turnover intention at Sari Mulia Hospital.

\section{RESEARCH METHODS}

This research is an analytic observational research with cross sectional approach. Analytic observational research, which is to look for the relationship between independent variables (indenpen) with the dependent variable (dependent) whose analysis is to determine whether there is a relationship between variables so that the hypothesis needs to be arranged (10). The methodology design used is to look for the influence variable that is the effect of work period and compensation for the affected variable, namely the intention to move the nurse's work at Sari Mulia Hospital, Banjarmasin.

The population in this study were all nurses at the Sari Mulia Hospital in Banjarmasin totaling 147 people with the criteria that they were not on leave or permission and the length of work was more than 3 months. In this study using probability sampling is a sampling technique that provides equal opportunities for each member of the population to be selected as a sample member that is sampling the population member is done randomly without regard to strata that exist in that population (11). So, the number of respondents in this study was 60 people.

The research instrument used in this study is a closed questionnaire that has provided the answers so that respondents just choose the appropriate answer. The advantage of using a questionnaire is that it can be shared simultaneously with respondents. The questionnaire was tested for the validity and reliability of the instrument at Banjarmasin Suaka Insan Hospital on 30 nurses.

\section{RESULTS AND DISCUSSION}

Based on the results of a study of 60 respondents obtained the frequency distribution of respondents' work tenure presented in table 1 . 
Table 1. Frequency distribution based on the Nurse Service Period at Sari Mulia Hospital Banjarmasin.

\begin{tabular}{llll}
\hline No. & Age & f & \% \\
\hline 1 & $<30$ years & 17 & 28.3 \\
2 & $>31$ years & 43 & 71.7 \\
\hline & counts & 60 & 100 \\
\hline
\end{tabular}

Source : Primary data, 2017

Based on table 1 it was found that of the 60 respondents the most were nurses with an age over 30 years as many as 43 people $(71.1 \%)$ while nurses who were less than 30 years old were only 17 people $(28.3 \%)$.

Table 2. Frequency distribution based on nurse education at Sari Mulia Hospital Banjarmasin

\begin{tabular}{cccc}
\hline No. & Education & $\mathbf{f}$ & $\%$ \\
\hline 1 & DI / SPK & 0 & 0.0 \\
2 & DIII & 46 & 76.7 \\
3 & S1 & 14 & 23.3 \\
\hline & Counts & 60 & 100 \\
\hline
\end{tabular}

Source : Primary data, 2017

Based on table 2 it is known that of the 60 respondents the most nurse education was DIII education as many as 46 people $(76.7 \%$ ) while S1 education amounted to 14 people (23.3\%)

Table 3. Frequency distribution based on marital status of nurses at Sari Mulia Hospital Banjarmasin

\begin{tabular}{cccc}
\hline No. & Marital Status & f & \% \\
\hline 1 & Married & 47 & 78.3 \\
2 & Not Married & 13 & 21.7 \\
\hline & Counts & 60 & 100 \\
\hline
\end{tabular}

Source : Primary data, 2017

Based on table 3 it is known that of the 60 respondents marital status of nurses the most is already married as many as 47 people $(78.3 \%)$ while the unmarried numbered 13 people $(21.7 \%)$.

Table 4. Frequency distribution based on gender of nurses at Sari Mulia Hospital Banjarmasin.

\begin{tabular}{cccc}
\hline No. & Gender & f & \% \\
\hline 1 & Male & 17 & 28.3 \\
2 & Women & 43 & 71.7
\end{tabular}




\begin{tabular}{lll}
\hline Counts & 60 & 100 \\
\hline Source : Primary data, 2017 & &
\end{tabular}

Based on table 4 it is known from the 60 respondents that the most sex nurses are women as many as 43 people $(71.7 \%)$ while the men only number 17 people $(28.3 \%)$.

Table 5. Frequency distribution based on Nurse Compensation at Sari Mulia Hospital Banjarmasin.

\begin{tabular}{cccc}
\hline No. & Compensation & $\mathbf{f}$ & \% \\
\hline 1 & Good & 27 & 45 \\
2 & Enaugh & 33 & 55 \\
\hline & Counts & 60 & 100 \\
\hline
\end{tabular}

Source : Primary data, 2017

Based on table 5 it is known from 60 respondents that the most nurse compensation was with enough compensation as many as 33 people $(55 \%)$ while both numbered 27 people $(45 \%)$.

Table 6. Frequency distribution based on length of service of nurses at Sari Mulia Hospital Banjarmasin.

\begin{tabular}{cccc}
\hline No. & Working Period & $\mathbf{f}$ & \% \\
\hline 1 & $\leq 3$ years & 20 & 33.3 \\
2 & $>3$ years & 40 & 66.7 \\
\hline & Counts & 60 & 100 \\
\hline
\end{tabular}

Source : Primary data, 2017

Based on table 6 it is known from 60 respondents that the most tenure of nurses is with more than 3 years of service as many as 40 people $(66.7 \%)$ while those less than 3 years amount to 20 people $(66.7 \%)$

Table 7. Frequency distribution based on nurse's turnover intention at Sari Mulia Hospital Banjarmasin.

\begin{tabular}{cccc}
\hline No. & Turnover Intention & f & \% \\
\hline 1 & There is Intention & 32 & 53.3 \\
2 & None & 28 & 46.7 \\
\hline & Counts & 60 & 100 \\
\hline
\end{tabular}

Source : Primary data, 2017

Based on table 7, it is known from 60 respondents that the turnover intention of nurses is 32 people $(53.3 \%)$ while there are 28 nurses $(46.7 \%)$.

In this study, the types of independent and dependent variables are catagoric, so as to find out whether there is an influence of tenure on the intention to change employment and whether there is an effect of compensation on the intention to move the nurse using the chi-square test analysis. To test the significance level, the p-value value is used using a significance level of 5\% and a degree 
of confidence of $95 \%$. So that it can be explained that the p-value $\leq 0.05$ then shows that there is a relationship between the dependent variable and the independent variable and if $p$-value $>0.05$, then there is no relationship between the dependent variable and the dependent variable. The factors that most influence nurse turnover intention are compensation.

Table 8. Effect of compensation on nurse turnover intention at Sari Mulia Hospital Banjarmasin.

\begin{tabular}{cccccccc}
\hline & \multicolumn{3}{c}{ Intention Turnover } & \multicolumn{2}{c}{ Total } & \multicolumn{1}{c}{$p$-value } \\
\cline { 2 - 7 } Compesation & \multicolumn{2}{c}{ There is intention } & None & & & \\
\cline { 2 - 7 } & $\mathrm{N}$ & $\%$ & $\mathrm{~N}$ & $\%$ & $\mathrm{n}$ & $\%$ \\
\hline Good & 9 & 28.1 & 18 & 64.3 & 27 & 45 \\
\hline Enaugh & 23 & 71.9 & 10 & 35.7 & 33 & 55 & 0,005 \\
\hline
\end{tabular}

Source : Primary data, 2017

Based on table 8 it is known that nurses' compensation is in the good category ie there is no intention to turnover as many as 18 people $(64.3 \%)$, there are intentions as many as 9 people (28.1\%) while nurse compensation is in the adequate category ie there is no intention of turnover as much as 10 people (35.7\%), there are intentions of 23 people $(71.9 \%)$. Statistical test results with a significance level $(\alpha)$ of $5 \%$, so that the p-value is smaller than the alpha value $(0.05)$ obtained p-value $=0.005$ which means that there is a significant influence between compensation for nurse turnover intention at Sari Mulia Hospital Banjarmasin.

The results of this study are in line with opinion (4) which reveals that the implementation of a fair and proper compensation system will prevent the intention to turnover. The results of this study are in line with research (15) that compensation has a negative and significant effect on intention to turnover meaning that if compensation increases then intention to turnover will decrease and if compensation decreases then intention to turnover will increase.

This shows that the compensation is enough to cause nurses at Sari Mulia hospital to leave the hospital and look for a better job. If the compensation increases, the intention to change work will decrease, and vice versa if the compensation decreases, the nurse's intention to act will increase. Based on the analysis results for the compensation variable that has the most influence is salary, this shows that the salary received by nurses at Sari Mulia Hospital is not yet according to UMR standards. Nurses with enough salary will always think of getting out of the hospital and continue to look for work information elsewhere that might offer a higher salary. Nurses whose salaries are still sufficient will also continue to see better job opportunities elsewhere or will even look for side jobs, this will trigger negative behaviors such as absenteeism and lethargy which will have an impact on the desire to leave or change work.

Simultaneous test in this study to prove whether the independent variables affect the dependent variable. Simultaneous test results using logistic regression through a computerized system obtained the following data:

Table 9. Multivariate Analysis 


\begin{tabular}{|c|c|c|}
\hline No & Variabel & $p$-value \\
\hline 1 & Working period & 0,175 \\
\hline 2 & compensation & 0,006 \\
\hline 3 & Age & 0,889 \\
\hline 4 & Education & 0,371 \\
\hline 5 & Marital status & 0,991 \\
\hline 6 & Gender & 0,858 \\
\hline
\end{tabular}

Source : Primary data, 2017

Based on multivariate analysis with multiple logistic regression it can be concluded that of the six variables most influential on turnover intention is compensation with a p-value of 0.006 .

According to (16) turnover intention is the tendency of employee's intention to move to quit or quit his job voluntarily or move from one work place to another according to his own choice by reason of compensation, work convenience, leadership problems. (17) defines that the intention to change work is the last step of a person's behavior in decision making where a nurse actively considers quitting her job and is looking for other work alternatives. The desire to move nurses to work at the Sari Mulia Banjarmasin hospital is influenced by many factors and the compensation factor has a significant effect on turnover intention.

\section{CONCLUSION}

Based on the results of the study, it can be concluded that the variables of tenure, age, education, marital status and gender do not significantly influence nurses turnover intention at Sari Mulia Hospital, meaning that these variables do not contribute significantly to nurses turnover intentions. Whereas nurse compensation is classified as sufficient with the level of achievement of respondents for sufficient category compensation, it means that compensation has a significant effect on turnover intention with a p-value of 0.005 . Based on simultaneous analysis (joint analysis) each independent variable on the intention to change work is done using multivariate analysis with multiple logistic regression. Of the six variables that influence nurse turnover intention at Sari Mulia Hospital is compensation.

Efforts to reduce the incidence of nurses who intend to move to work should be Sari Mulia hospital must also pay attention to the Government Regulation regarding the provisions of the Regional Minimum Wage (UMR) which will be the basis for providing the basic salaries of nurses. Evaluate the compensation system according to the nurse's length of service. Sari Mulia Hospital is expected to always maintain or continue to improve training for nurses to develop their careers in the future. It is hoped that the results of this study can be used as a reference for further researchers, variables that can be developed include workload, supervision and organizational commitment. 


\section{REFERENCES}

[1]. Langitan, Rosamey Elleke. Faktor-faktor yang mempengaruhi Kejadian Turnover Perawat Pelaksana Tahun 2009 di Rumah Sakit Bhakti Yudha Depok. Tesis. Depok : Fakultas Ilmu Keperawatan Universitas Indonesia; (2010).

[2]. As'ad, M. Psikolog Islami : Seri Sumber Daya Manusia. Yogyakarta : Liberty; (2003).

[3]. Gillies, Dee Ann. Nursing Management : A System Approach Third Edition. Philadelphia: W.B. Saunders Campany; (1994).

[4]. Muthiah, A. Pengaruh Stres kerja, Iklim Organisasi, Kompensasi, Lingkungan Kerja dan Karakteristik Pekerjaan terhadap Turnover Intention dengan Kepuasan Kerja sebagai Variabel Intervening. Tesis, Universits Terbuka Jakarta; (2012).

[5]. Simamora, Henrry. Manajemen Sumber Daya Manusia. STIE, Yogyakarta; (2006).

[6]. Ranupandojo, H., Suad Husnan. Manajemen Personalia, Yogyakarta: BPFE; (2006).

[7]. Handoko, Hani. Manajemen Personalia \& Sumberdaya Manusia. Edisi Kedua. Yogyakarta : BPFE UGM; (2010).

[8]. Hasibuan Malayu S.P. Manajemen Sumber Daya Manusia Edisi Revisi. Jakarta: Bumi Aksara. (2011).

[9]. Robbins, S.P dan Judge, T.A. Perilaku Organisasi, Jilid 1 dan 2, Edisi ke-22. Jakarta: Prenhallindo; (2007).

[10]. Nursalam. Konsep dan Prinsip Metodologi Riset Keperawatan. Jakarta : Salemba Medika; (2003).

[11]. Sugiyono. Metode Penelitian Kuantitatif, Kualitatif dan $R \& D$. Cetakan ke-19. Bandung : Alfabeta; (2013).

[12]. Najamuddin, M. Faktor yang mempengaruhi Niat Pindak Kerja (Turnover Intention) pada bidan desa di Kabupaten Bululumba. Universitas Hasanuddin Makassar; (2013).

[13]. Desa, M., Rini, E., Syarifah. Pengaruh Sosiodemografi dan Karakteristik Pekerjaan terhadap Keinginan Pindah Bidan Di Kabupaten Serdang Berdagai. Universitas Sumatera Utara, Medan; (2008).

[14]. Desa, M., Rini, E., Syarifah. Pengaruh Sosiodemografi dan Karakteristik Pekerjaan terhadap Keinginan Pindah Bidan Di Kabupaten Serdang Berdagai. Universitas Sumatera Utara, Medan; (2008).

[15]. Yanita, P dan Masdupi, E. Pengaruh Kompensasi, Komitmen Organisasi Dan Job InsecurityTerhadap Intention To Turnover Pada Dosen Sekolah Tinggi Ilmu Ekonomi Sakti Alam Kerinci (Stie Sak) Tesis; (2013).

[16]. Mobley, W. H. Pergantian karyawan Sebab Akibat dan Pengendaliannya. Jakarta: PPM dan Bisnis 2030; (2011).

[17]. Meyer dan Tett. (1993). Job Satisfaction, Organizational Commitment, Turnover Intention and Turnover. Personnel Psychology; (1993). 